\title{
Vasculaire verkalking
}

Citation for published version (APA):

Schurgers, L. J. (2018). Vasculaire verkalking: een hard-nekkig probleem. Maastricht University. https://doi.org/10.26481/spe.20181012ls

Document status and date:

Published: 12/10/2018

DOI:

$10.26481 /$ spe.20181012ls

Document Version:

Publisher's PDF, also known as Version of record

\section{Please check the document version of this publication:}

- A submitted manuscript is the version of the article upon submission and before peer-review. There can be important differences between the submitted version and the official published version of record.

People interested in the research are advised to contact the author for the final version of the publication, or visit the DOI to the publisher's website.

- The final author version and the galley proof are versions of the publication after peer review.

- The final published version features the final layout of the paper including the volume, issue and page numbers.

Link to publication

\footnotetext{
General rights rights.

- You may freely distribute the URL identifying the publication in the public portal. please follow below link for the End User Agreement:

www.umlib.nl/taverne-license

Take down policy

If you believe that this document breaches copyright please contact us at:

repository@maastrichtuniversity.nl

providing details and we will investigate your claim.
}

Copyright and moral rights for the publications made accessible in the public portal are retained by the authors and/or other copyright owners and it is a condition of accessing publications that users recognise and abide by the legal requirements associated with these

- Users may download and print one copy of any publication from the public portal for the purpose of private study or research.

- You may not further distribute the material or use it for any profit-making activity or commercial gain

If the publication is distributed under the terms of Article $25 \mathrm{fa}$ of the Dutch Copyright Act, indicated by the "Taverne" license above, 


\section{Maastricht University}

Inaugurele rede

\section{Prof. dr. Leon J. Schurgers}

Faculty of Health, Medicine and Life Sciences

\section{Vasculaire verkalking: een hard-nekkig probleem}

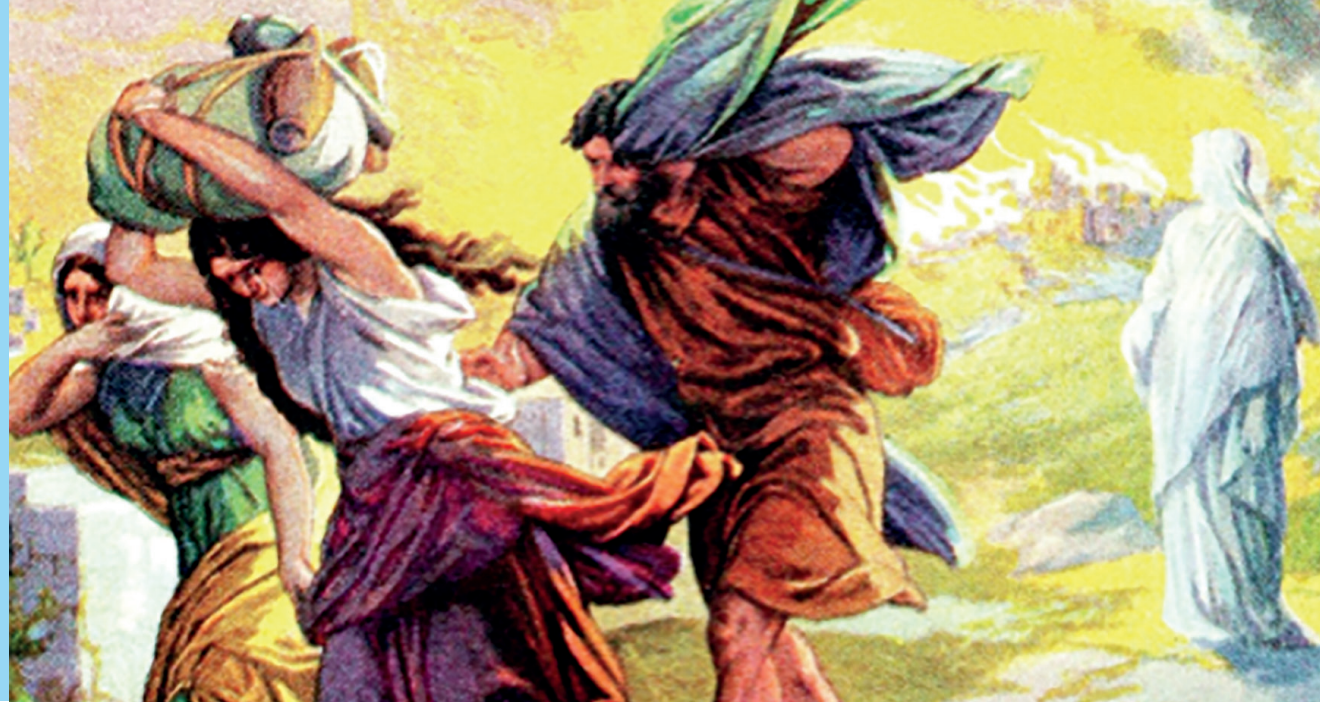


Vasculaire verkalking: een hard-nekkig probleem 


\section{Colofon}

Ontwerp en print: Leon Schurgers en Andi smart print solutions

Illustratie omslag: Genesis 19:26 (Illustration source Bible Primer 1919)

NUR: 915

Alle rechten voorbehouden. Niets uit deze uitgave mag worden verveelvoudigd, opgeslagen in een geautomatiseerd gegevensbestand of openbaar gemaakt worden, zonder voorafgaande schriftelijke toestemming van de auteur of uitgever. 


\section{Vasculaire verkalking: een hard-nekkig probleem}

\section{Rede}

Uitgesproken bij de aanvaarding van het ambt van hoogleraar in de Biochemie van vasculaire verkalking aan de Faculty of Health, Medicine and Life Sciences van de Universiteit Maastricht

Maastricht, 12 oktober 2018

Door Prof. dr. Leon J. Schurgers 
Imagination is more important than knowledge. - Albert Einstein 
Geachte prorector

Waarde collega's,

Lieve familie en vrienden

Geachte toehoorders

Wat fijn dat jullie er allemaal zijn!

Ik sta hier vandaag voor $U$ om mijn vak te presenteren, de biochemie van vasculaire verkalking, de leerstoel die ik ga vertegenwoordigen aan de Universiteit te Maastricht. Daar ben ik heel trots op. Zowel op mijn leerstoel, maar ook dat deze aan de Universiteit van Maastricht is, en vooral bij de afdeling Biochemie. Maastricht is de oudste stad van Nederland en Maastricht is mede bekend omdat hier meer dan 25 jaar geleden het verdrag van Maastricht is getekend: de geboorteakte van de Europese Unie. Europa wordt steeds belangrijker: meer veiligheid en stabiliteit, welvaart, en praktische voordelen zoals vrij reizen, wonen en werken in Europese deelstaten. In een speech vorige maand van Frans Timmermans op de opening van ons academisch jaar werd het belang van één Europa nogmaals benadrukt.

\section{Department of Biochemistry is here! ridenembiti
inside}

\section{Figuur 1}

Voor dat ik verder ga, sta mijn toe de niet-Nederlandse gasten hier aanwezig kort toe te spreken.

Dear friends and colleagues from abroad - I want to thank you for taking the effort to come over to Maastricht, the center of Europe. It is a true honor and pleasure for me that so many people from all over the world are present today. I apologize for doing this public lecture in Dutch.

Liebe familie, sehr geehrte Kolleginnen und Kollegen, vielen dank dass Ihr nach Maastricht gekomen seit, dass centrum Europa's. Ich bin sehr verehrt dass ihr heute hier seit. Ich mochte mich bei ihnen entschuldigen dass meine offenbare rede heute in Niederländisch sein wird.

Terug naar het Nederlands: Ik neem jullie mee terug in de tijd - mijn ouders, beide geboren tijdens de oorlog hier in de buurt. Mijn moeder aan de Nederlandse kant van de grens, mijn vader aan de Duitse kant. Ik, geboren in Duitsland, opgegroeid in Nederland. Op mijn $12^{\text {de }}$ genaturaliseerd tot Nederlander, en nu woon ik weer in Duitsland. In mijn jeugdjaren was dit niet altijd makkelijk, want één Europa was ver te zoeken en het waren vooral twee verschillende werelden. Alleen met voetballen was het wel handig om ook voor Duitsland te zijn, zo werd je tenminste nog eens wereldkampioen. Toen, met een fysieke grens tussen beide landen, iets dat mijn kinderen nooit hebben meegemaakt. Ik kon toen niet weten dat het één Europa zou worden, zonder grenzen, en dat ik een echte European ben. 
En waar beter dan in Maastricht zou ik me thuis voelen, de stad van Europa. Daarnaast is het verdrag van Maastricht getekend in de grotten van Canne, meer specifiek, in de mergelgrotten. Maastricht is namelijk ook bekend van de mergel - de stad van de $\mathrm{ENCl}$ - waar van kalksteen uit de regio cement wordt gemaakt. Kalk is dus onlosmakelijk met Maastricht verbonden. Waar anders zou een leerstoel over verkalking van bloedvaten moeten zijn dan in Maastricht.

Mijn vak: de biochemie van vasculaire verkalking. Biochemie - vrij vertaald de chemie van het leven, en dan gericht op kalkafzettingen in de bloedvaten. In het Nederlands wordt dit ook vaak aderverkalking genoemd, maar dat is niet juist. We kijken namelijk naar de verkalking van de slagaders en niet naar de aders. Mijn onderzoek richt zich specifiek op slagaderverkalking ofwel vasculaire verkalking. Verkalking is niet altijd gezien als een relevant probleem. Toen ik mijn onderzoek ongeveer 20 jaar geleden startte, werd verkalking gezien als een passief proces, een consequentie van onderliggende ziekten, een eindstadium. $\mathrm{k}$ werd zelfs geadviseerd mij met een "actief", en niet met een "passief" onderwerp bezig te houden.

Ik ga $\mathrm{u}$ in de komende drie kwartier uitleggen waarom juist het onderzoek naar kalk het cement vormt tussen verschillende onderzoekslijnen binnen onze eigen Universiteit en ook met andere onderzoekers in Europa.

\section{Deel 1: Kalk, een hard-nekkig probleem}

Hart en vaatziekten zijn nog steeds doodsoorzaak nr. 1 in de Westerse wereld. Dit aantal blijft stijgen en is geassocieerd met voedings-, leefstijl- en milieu-factoren. Het is verleidelijk te concluderen dat hartvaatziekten uitsluitend een probleem van de moderne samenleving is, en dat dit geen invloed heeft gehad op onze oude voorouders.
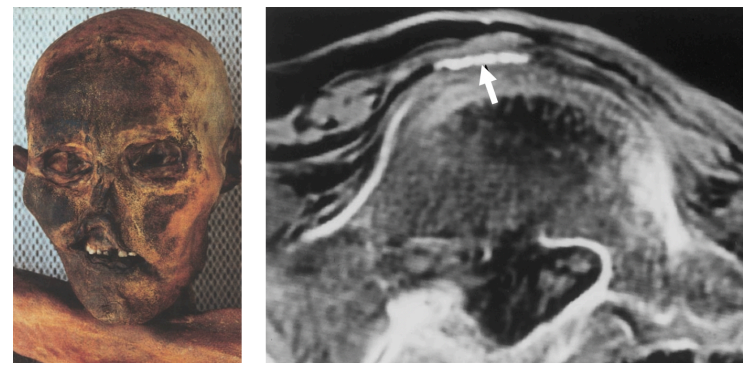

\section{Figuur 2}

Het is september 1991 als een Duits echtpaar uit Neurenberg tijdens een wandeling over een besneeuwde bergpas nabij het Ötztal in de Tiroolse Alpen een lichaam ontdekt. Het lichaam ligt ondersteboven, geheel bevroren en ingekapseld in ijs. In het jaar 1991 zijn er tenminste zes lijken gevonden en bevrijd uit de gletsjers in de Alpen. Gletsjer lichamen zijn typisch van personen die in de afgelopen decennia verdwaald zijn en overvallen door het slechte weer, vaak bergbeklimmers. Dit lijk was echter veel ouder. 
Resultaten van koolstofdatering, een nauwkeurige methode om de ouderdom van organisch materiaal vast te stellen, geven aan dat het lichaam meer dan 5.000 jaar oud is. Deze bevroren mummie wordt ook wel Ötzi genoemd, hier links aangegeven op het scherm. Rechts ziet U een CT-scan gemaakt van de onderbuik van Ötzi. Een CT-scan is een röntgenapparaat dat een serie foto's maakt waarmee een bloedvat plakje voor plakje wordt weergeven. De kalk in de bloedvaten heeft dezelfde dichtheid als de kalk in de botten. De witte pijl toont de ernstige verkalking van de aorta, de grote lichaamsslagader ${ }^{1}$.

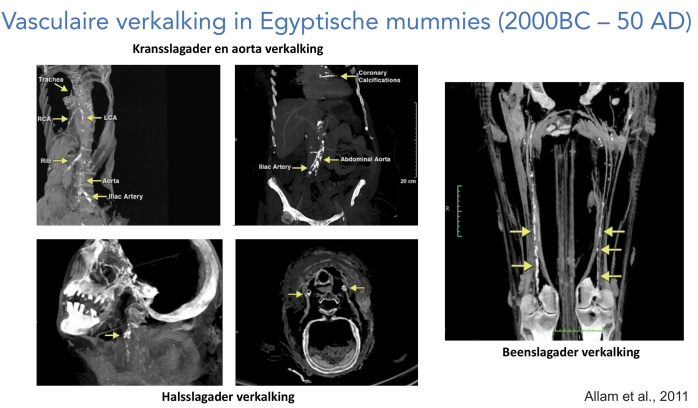

Figuur 3

Ook in Egyptische mummies, beschikbaar gesteld door het museum in Cairo, is verkalking aangetoond. Er zijn CT-scans gemaakt van 52 mummies die hebben geleefd tussen 2000 voor Christus tot 50 na Christus. De gemiddelde leeftijd bij overlijden is 40 jaar. Hierboven mij ziet $\mathrm{u}$ dat verkalkingen zijn aangetoond in de slagaders van het hart, de hals, en de benen. Deze beelden laten zien dat verkalking geen welvaartziekte is ${ }^{2}$.

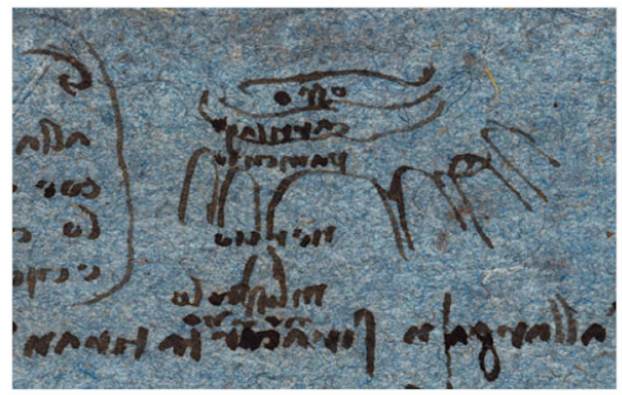

Fig.4.47 This small drawing of a mitral valve leaflet shows a layer of calcification that occurs in mitral valve rheumatic disease. Detail from RL 19093 recto, Studies of the heart, and the head of a youth in profile. Leonardo da Vinci, c. 1511-13. Pen and ink on blue paper (Lent by Her Majesty The Queen. Royal Collection (c) Her Majesty Queen Elizabeth II)

Leonardo da Vinci 1452 - 1519

Figuur 4 
De eerste aanwijzingen voor vasculaire verkalking worden lang voor het CT-tijdperk al beschreven. De eerste tekeningen van verkalkte hartkleppen zijn van Leonardo da Vinci uit 1511. In deze tijd wordt verkalking vooral gezien als een afspiegeling van leeftijd.

We maken een sprong naar het jaar 18 honderd, als wordt omschreven dat arteriosclerose een gevolg is van ontstekingen in de vaatwand ${ }^{3}$. De samenstelling van de zieke vaatwand werd geanalyseerd met behulp van "micro-inceneration" ofwel het cremeren. Deze techniek omvat het verbranden van biologische monsters om zo de distributie van mineralen aan te tonen. Het bleek dat meer dan $65 \%$ van de ontstoken vaatwand bestond uit calciumfosfaat. Ondanks dat deze techniek zeer oud is, geeft deze een nauwkeurige beschrijving en analyse van de verkalking. Helaas dreigen deze gedetailleerde technieken verloren te gaan. Het is daarom mijn advies, de oude literatuur er eens vaker op na te slaan.

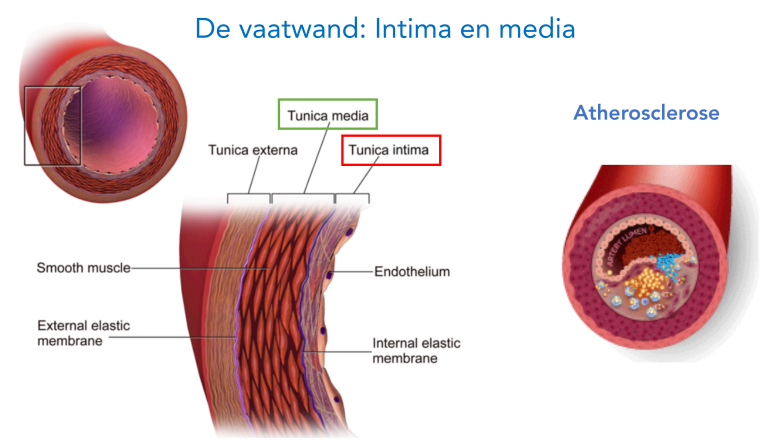

\section{Figuur 5}

Verkalking kan plaatsvinden op verschillende anatomische locaties zoals in de hartkleppen en in de vaatwand. In de vaatwand kan de verkalking in twee lagen voorkomen.

De tunica intima, hier met het rode blokje aangegeven en in de tunica media, het blokje in het groen. De grondleggers voor deze definities zijn twee Duitse pathologen. Rond 1860 beschrijft de arts Rudolph Virchow het proces van atherosclerose waarbij hij verkalking als botvorming in de vaatwand omschrijft ${ }^{4}$. In 1902 publiceert de Duitse patholoog Johannes Mönckeberg dat verkalking ook aanwezig kan zijn in tunica media. De kalk in de mediale spierlaag wordt ook wel Mönckeberg's sclerose genoemd ${ }^{5}$.

Mediale en intimale verkalking zijn dus twee afzonderlijke processen met afzonderlijke risico factoren. In figuur 7 ziet $u$ dat intimale verkalking is geassocieerd met traditionele risico factoren zoals roken, hoog cholesterol en ontsteking. De verkalking is voornamelijk diffuus. Mediale verkalking is geassocieerd met ziektes zoals diabetes en nierfalen en heeft vaatwand stijfheid tot gevolg. Dit wordt gekenmerkt door een ringachtige verkalking van de vasculaire media van bloedvaten, zonder ontsteking van de vaatwand. Deze twee verkalking processen zijn afzonderlijke processen. Maar ze komen ook samen voor. 


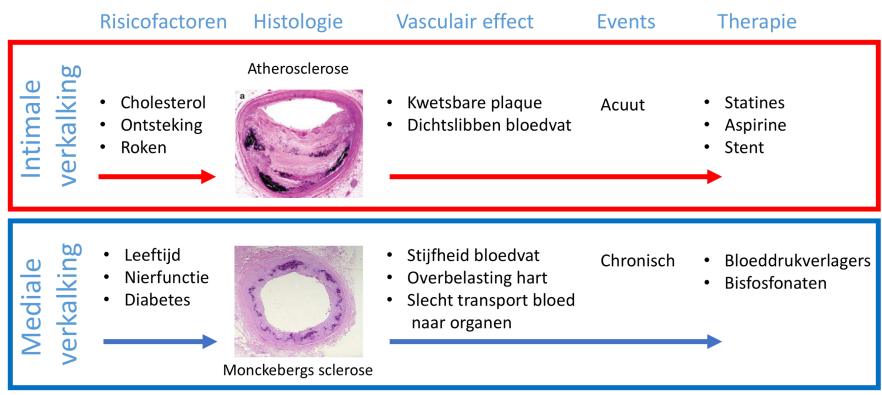

\section{Figuur 6}

In onderzoek van bijna 75 jaar geleden laat uitvoerige pathologische analyse van 540 aorta's zien dat verkalking van de media sterk is geassocieerd met leeftijd. $U$ kunt uit deze grafiek aflezen dat $90 \%$ van de mensen voor hun 50 st levens jaar kalk in de vaatwand heeft. Ook is in deze figuur te zien dat deze mediale verkalking voorafgaat aan de vorming van atherosclerose ${ }^{6}$.

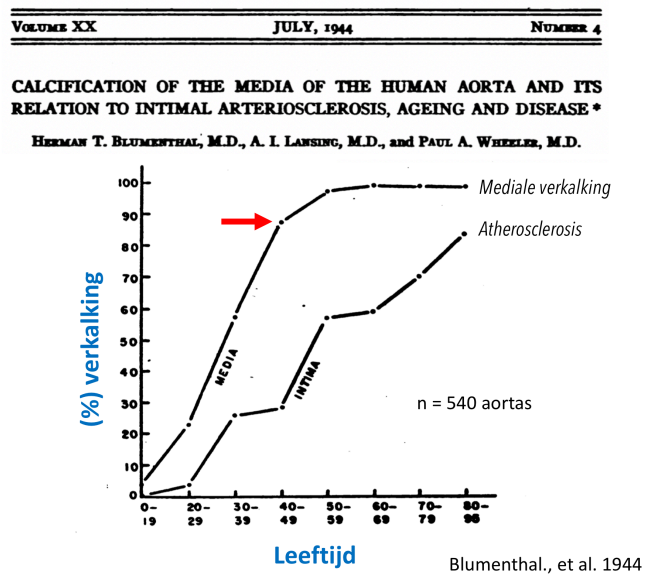

Figuur 7

Ik hoop dat u ondanks deze hard-nekkige feiten, er niet al te stijfjes bij zit...

Toch verdwijnt het verkalking onderzoek naar de achtergrond. De alom heersende gedachte is dat klassieke risico factoren zoals cholesterol en ontsteking een veel grotere rol spelen bij hart en vaatziekten. Verkalking wordt, mede door de slechte resolutie van kransslagader angiografie als een eindstadium van de ziekte gezien. Ook maakt men door de slechte resolutie geen onderscheid meer tussen mediale en intimale verkalking. 
De wetenschappelijke belangstelling voor verkalking barst weer los in de begin jaren van de 21st eeuw, toen duidelijk werd dat verkalking in beeld gebracht met CT, gebruikt kon worden als marker voor hartvaatziekte en als marker voor kans op overlijden. Er verschijnen vele publicaties die de rol van verkalking in hart en vaatziekte en sterfte beschrijven, en ik zal hier niet ingaan op de vele individuele studies.

Aanwezigheid van vasculaire verkalking en kans op overlijden

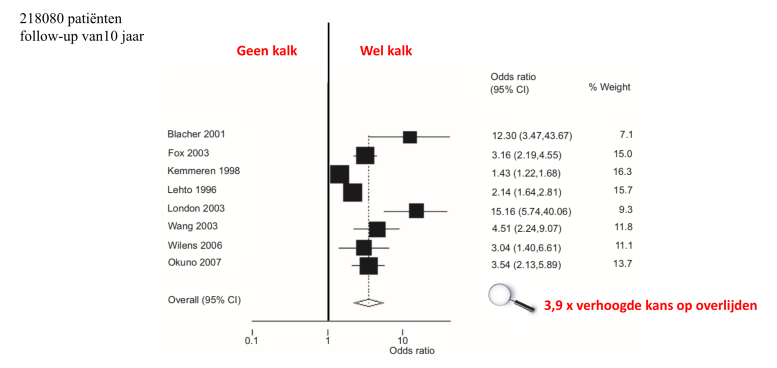

Figuur 8

Rennenberg et al., 2009

In samenwerking met de afdeling Interne Geneeskunde van Profs. Kroon en de Leeuw en Dr. Rennenberg hebben we dit samengevat, en een meta-analyse uitgevoerd. Een meta-analyse is een onderzoek waarbij de resultaten van eerder uitgevoerde en gepubliceerde onderzoeken samen worden genomen om een precieze uitspraak te doen over een bepaald fenomeen, in ons geval verkalking. In dit onderzoek zijn 30 studies meegenomen waarin meer dan 200 duizend patiënten worden beschreven. Patiënten zijn onderverdeeld in geen kalk of wel kalk aanwezig in de bloedvaten. Uit dit onderzoek bleek dat het risico op overlijden vele malen hoger is als er kalk aanwezig is in de bloedvaten. Het maakte hierbij niet uit in welk bloedvat of hartklep de kalk gemeten is, of met welke methode. Bij de aanwezigheid van kalk, is er een bijna 4 keer verhoogde kans op overlijden ${ }^{7}$.

De ontwikkeling van de atherosclerotische laesie

\begin{tabular}{|c|c|c|}
\hline Type I & Initiële laesie & $\begin{array}{l}\text { Microscopische laag spiercellen, matrix en } \\
\text { enkele ontstekingscellen }\end{array}$ \\
\hline $\begin{array}{c}\text { Type II } \\
\text { Ila } \\
\text { lla }\end{array}$ & $\begin{array}{l}\text { Progressieve-gevoelige laesie } \\
\text { Progressieve-ongevoelige laesie }\end{array}$ & $\begin{array}{l}\text { Lokale ophoping van schuimcellige macrofagen } \\
\text { en lymfocyten }\end{array}$ \\
\hline Type III & Preatheroma laesie & $\begin{array}{l}\text { Beginnende extracellulaire stapeling } \\
\text { van lipiden }\end{array}$ \\
\hline Type IV & Atheroma laesie & $\begin{array}{l}\text { Grote kern van extracellulaire lipiden (atheroom), } \\
\text { infiltratie met ontstekingscellen en dunne fibreuze kap }\end{array}$ \\
\hline Va & Collageen atheroma laesie & Va: atheroom met een of meer fibreuze kappen \\
\hline $\mathrm{Vb}$ & Kalk atheroma laesie & $\mathrm{Vb}$ : atheroom met uitgebreide verkalkingen \\
\hline Vc & Collageen laesie & Vc: gefibroseerd atheroom, weinig lipiden \\
\hline Type VI & Trombose / Infarct & $\begin{array}{l}\text { Ruptuur of erosie en trombusvorming of } \\
\text { intraplaquebloeding }\end{array}$ \\
\hline
\end{tabular}

Figuur 9 
Alvorens ik met $\mathrm{u}$ de rol van verkalking bij atherosclerose bespreek, geef ik u eerst een korte les over de ontwikkeling van een atherosclerotische plaque. Atherosclerose kan op basis van de ontwikkeling worden onderverdeeld in verschillende fases. Deze indeling gebeurt door een patholoog op basis van verkregen vaatweefsel. Het Romeinse cijfer I wordt gebruikt voor de eerste fase, waarin een kleine verdikking van de vaatwand te zien is. Het Romeinse cijfer VI is de hoogste categorie en wordt gekarakteriseerd door ernstige mate van verdikking van de vaatwand. Deze kwetsbaar laesie kan openbarsten en het bloedvat helemaal afsluiten met een stolsel: dit noemen we dan een hersen- of hartinfarct. Zoals $u$ kunt zien in deze classificatie is verkalking pas aanwezig vanaf de fase aangeduid met het Romeinse cijfers $\mathrm{Vb}$.

Nu streeft de wetenschap naar fundamentele kennis en begrip van de werkelijkheid. Hierbij wordt getracht de werkelijkheid te weerleggen. Weerlegging werkt zuiverend en is essentieel omdat het leidt tot verbetering van de theorie en tot nieuwe experimenten en inzichten. Wellicht kunt $u$ het al vermoeden, maar de werkelijkheid dat verkalking een eindstadium van hartvaatziektes zou zijn, moet mijns inziens worden weerlegt.

De huidige resolutie van een CT is ongeveer $200 \mu \mathrm{m}$, terwijl de vroegste vormen van verkalking vele malen kleiner zijn. Deze microverkalkingen zijn ongeveer 1 tot $15 \mu \mathrm{m}$ in grootte. Om aan te geven hoe groot $1 \mu \mathrm{m}$ is; dit is 1 miljoenste van een meter. Of anders gezegd, ongeveer 1000x kleiner dan de dikte van een vingernagel. Juist deze microverkalkingen zijn het gevaarlijkst, omdat ze kunnen leiden tot kleine rupturen. ledere keer als het bloed met kracht tegen de wanden van de bloedvaten drukt, ontstaat er frictie rondom deze kleine harde kalkkristallen. Deze kleine rupturen zullen uiteindelijk leiden tot een fatale ruptuur, met een hartof herseninfarct tot gevolg.

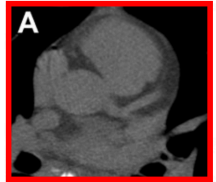

Geen verkalking Type I - IV

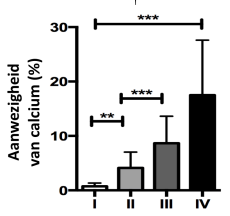

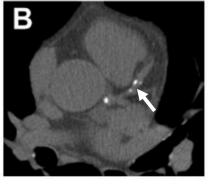

Matige verkalking Type V

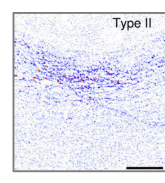

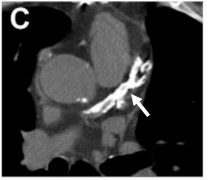

Ernstige verkalking Type $\mathrm{Vb}$

Figuur 10

In samenwerking met Prof. Ger van der Vusse van de afdeling fysiologie en Dr. Jack Cleutjens van de afdeling pathologie hebben wij weefsels met vroege stadia van atherosclerose geanalyseerd, dus de Romeinse cijfers I t/m IV, hier in de figuur aangegeven met de rode rand. Hierin zou dus nog geen kalk aanwezig moeten zijn. Deze samenwerking werd uitgebreid met de afdeling Kernfysica aan de TU Eindhoven, waar men de beschikking heeft over een Singletron. 
Hiermee kan een protonenbundel worden gegenereerd met een diameter van $1 \mu \mathrm{m}$. Als deze bundel een dun plakje humaan vaatweefsels bestraald, kan men de element-samenstelling hierin bepalen. Bij dit minutieus aftasten van de weefselplakjes waren wij in staat om zelfs in de vroegste fases van atherosclerose kleine calcium kristallen te detecteren. Het neerslaan van calcium zouten vindt dus al in een zeer vroeg stadium van hart en vaatziekte plaats ${ }^{8}$.

Omdat uit deze studie niet geconcludeerd kon worden of deze microverkalkingen de primaire oorzaak van atherosclerose zijn, of dat deze enkel een gevolg van de ziekte zijn, ontstond de behoefte voor verder onderzoek. Zulk onderzoek vergt een multidisciplinaire aanpak en er is veel arbeidskracht en geld nodig om betekenisvolle stappen te zetten. Ik memoreer het belang van Europa. Europa stelt veel onderzoeksbudget beschikbaar om samenwerkingen tussen verschillende landen te stimuleren en zo kennis te bundelen en te vergroten. Om dit doel te bereiken heb ik samen met collega Prof Hackeng en Prof Jahnen-Dechent uit Aken het consortium INTRICARE samengesteld.

\section{INTRICARE}

INTRICARE heeft als doel de nadelige effecten van micro-verkalking te stoppen door vroege detectie en interventie en hiermee de kwetsbare atherosclerotische plaque te voorkomen.

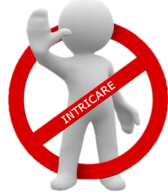

Coordinator: CARIM
15 PHDs; 4M€

WP1 - Rol van micro-verkalking bij de ontwikkeling van atherogenese

WP2 - Vasculaire remodelling geassocieerd met micro-verkalking WP3 - Imagen van microverkalking

Figuur 11

EUROPEAN COMMISSION Research Executive Agency (REA) Manie Skkodowska-Curie Innowative Training Networks
Head of Unit
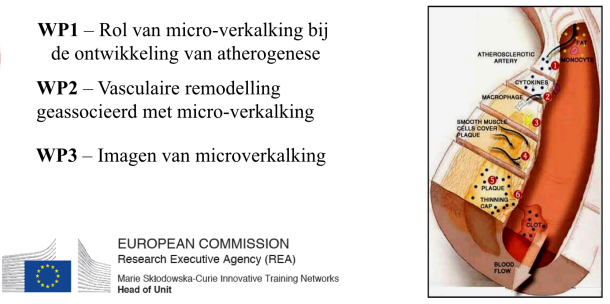

Dit consortium is in 2016 gehonoreerd door de Europese Unie met een Marie-SklodowskaCurie subsidie. Er werd ons 4 miljoen euro beschikbaar gesteld om 15 jonge veelbelovende studenten uit de hele wereld op te leiden in de breedste zin van het woord. Deze jonge wetenschappers krijgen intensieve training aan verschillende universiteiten in Europa. Ons consortium bestaat naast academische ook uit industriële partners, waardoor studenten ook valoriserend geschoold worden. Ons consortium heeft als doel het onderzoeken hoe microverkalkingen ontstaan, hoe deze de ontwikkeling van atherosclerose beïnvloeden, en hoe deze eerder ontdekt en aangetoond kunnen worden. Dit past zeer wel binnen de strategie van preventie en vroege detectie welke in Maastricht hoog in het vaandel staan.

Helaas staan hart en herseninfarcten nog steeds op nummer 1 en 2 in de top 10 van oorzaken waar mensen in de Westerse wereld aan overlijden. Juist hart- en herseninfarcten zijn sterk geassocieerd met intimale verkalking. Maar ook diabetes en nierfalen staan in de top 10: ziektebeelden die juist sterk geassocieerd zijn met mediale verkalking (http://www.who.int/newsroom/fact-sheets/detail/the-top-10-causes-of-death). 


\section{Top 10 oorzaken van sterfte}

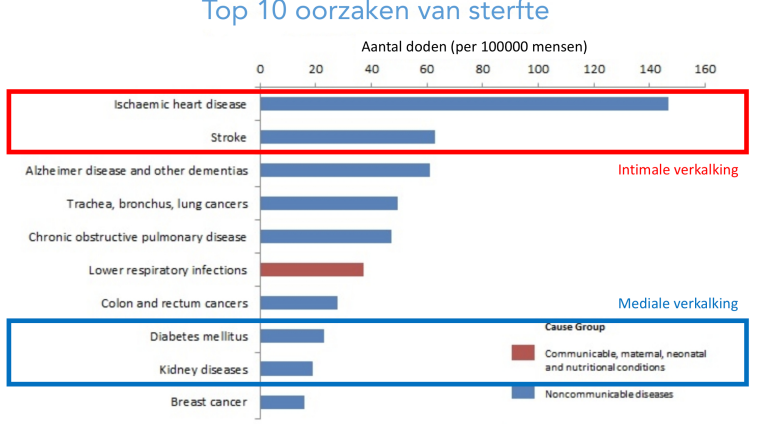

\section{Figuur 12}

Bij patiënten met diabetes type 2 of nierfalen, is mediale verkalking veelvuldig aanwezig. Mediale verkalking gaat bij deze patiënten gepaard met een 5 tot 10 maal verhoogd risico op hart en vaataandoeningen en overlijden ${ }^{9}{ }^{7}$. Verkalking is dus hard-nekkig aanwezig in deze top 10.

In onze bloedvaten zitten voornamelijk gladde spiercellen. Deze cellen zorgen voor het samentrekken van bloedvaten, en om deze functie uit te oefenen hebben ze calcium nodig. De concentratie aan calcium die nodig is in de cel bedraagt 100nM. De concentratie buiten de cel is $2 \mathrm{mM}$, dus een factor 20.000 hoger. Er bestaat dus een continu gevaar om te verkalken. In ons bloed zit namelijk naast de $2 \mathrm{mM}$ calcium ook nog eens $1 \mathrm{mM}$ fosfaat. ledereen die heeft opgelet tijdens de scheikunde les op de middelbare school weet dat deze concentraties het oplosbaarheidsproduct fors overschrijden. Er bestaat dus een constant Bijbels gevaar om in een zoutpilaar te veranderen (Genesis 19:26).

Oplosbaarheidsproduct calciumfosfaat: $\mathrm{Ca}_{3}\left(\mathrm{PO}_{4}\right)_{2}=2,1 \cdot 10^{-33}$
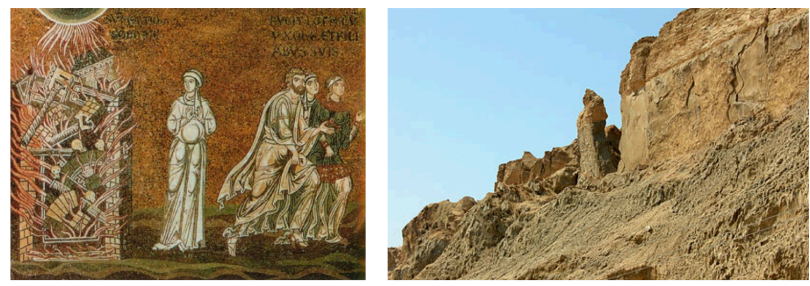

"Lot's Wife" pillar, Mount Sodom, Israel.

Figuur 13

Deze gladdespiercellen hebben dus enerzijds calcium nodig, en staan anderzijds onder continue druk te verkalken. Waarom heeft de evolutie dit probleem niet uitgeschakeld. Een mogelijke verklaring komt uit de hoek van de Evolutionaire of Darwiniaanse geneeskunde. Deze wetenschap tracht te begrijpen waarom natuurlijke selectie het lichaam kwetsbaar heeft gemaakt voor ziekte. Dit wordt omschreven als de antagonistische pleiotropie ${ }^{10}$. 


\section{PLEIOTROPY, NATURAL SELECTION, AND THE EVOLUTION OF SENESCENCE ${ }^{1}$}

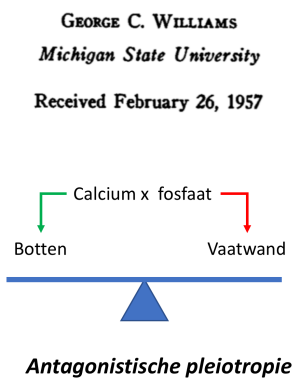

Figuur 14

Hierin wordt het hypothetische voorbeeld genomen, dat genen die een belangrijke rol spelen bij overleving zich in de reproductieve periode sterk ontwikkelen omdat dat dit het individu voordeel brengt in nageslacht. Echter, deze zelfde genen kunnen na de reproductieve periode nadelig zijn. Williams die dit principe in 1957 bedacht geeft als voorbeeld dat een sterke botvorming met goede verkalking belangrijk is voor overleving, maar als verkalking doorgaat in de vaatwand is dat nadelig. Dit is nooit een evolutionair probleem geweest: hart en vaatziekten ontstaan meestal pas in de post-reproductieve fase. Natuurlijke selectie heeft het uitschakelen van vasculaire verkalking dus verwaarloost.

Op dit punt in mijn betoog aangekomen is het van belang ons af te vragen hoe we onze bloedvaten kunnen beschermen tegen verkalking, aangezien de mens steeds ouder wordt.

Dit brengt mij tot het tweede deel van mijn openbare les: is verkalking een beïnvloedbare risico factor?

\section{Balans tussen remmers en stimulatoren van verkalking}

$\begin{array}{ll}\text { - matrix Gla protein } & \text { - BMP-2/4 } \\ \text { - osteopontin } & \text { - extracellulaire vesicles } \\ \text { - osteoprotegerin } & \text { - celdood } \\ \text { - fetuine A } & \text { - coog cholesterol } \\ \text { - FGF23 } & \text { - ontsteking } \\ \text { - klotho } & \text { - glucose } \\ \text { - pyrophosphate } & \text { - medicatie } \\ \text { - acid pH } & \\ & \\ \text { Remming van } & \text { Stimulering van } \\ \text { verkalking } & \text { verkalking }\end{array}$

Figuur 15

De mens is dus een superverzadigde zak van calcium en fosfaat zouten. Dat ik op dit moment hier voor u niet verander in een zoutpilaar komt door een ingenieus systeem dat ervoor zorgt dat verkalking plaatsvindt in de botten waar het moet en dit geremd wordt in zachte weefsels. Dit systeem bestaat uit een groot aantal eiwitten die ervoor zorgen dat calcium en fosfaat in oplossing blijven. 
Midden jaren 90 start ik mijn carrière bij de groep van Dr. Kees Vermeer. Zijn groep werkte aan vitamine $\mathrm{K}$ en vitamine K-afhankelijke eiwitten. Ik kreeg een vitamine K-project en dan gericht op de effecten hiervan op de vaatwand. Vitamine K-afhankelijke eiwitten hebben, zoals de naam suggereert vitamine $\mathrm{K}$ nodig voor hun functie.

H ENRIK DAM

The discovery of vitamin K, its biological

functions and therapeutical application

Nobel Lecture, December 12, 1946

Dam en Doisy delen de

Nobel Prijs in 1943 voor hun werk

aan vitamine $\mathrm{K}$

Figuur 16

Deze functie is ongeveer 100 jaar geleden ontdekt door de Deense onderzoeker Hendrik Dam, waarvoor hij de Nobelprijs kreeg. Dam deed onderzoek naar het vet metabolisme bij kippen. Maar wat gebeurde - zoals zo vaak in de wetenschap - was een toevalsbevinding. De kippen die het vetarme dieet kregen begonnen na een aantal dagen ernstige bloedingen te vertonen. Dam ontdekte dat dit kwam door een micro-nutriënt, een vet oplosbaar vitamine. De eerste letter in het alfabet die vrij was voor dit nieuwe vitamine was de letter "K", dus het werd vitamine K. Nu kwam dat ook goed uit, want het werk van Dam werd gepubliceerd in een Duits tijdschrift en men schrijft in het Duits stolling als "Koagulation met een " $\mathrm{K}$ " 11.

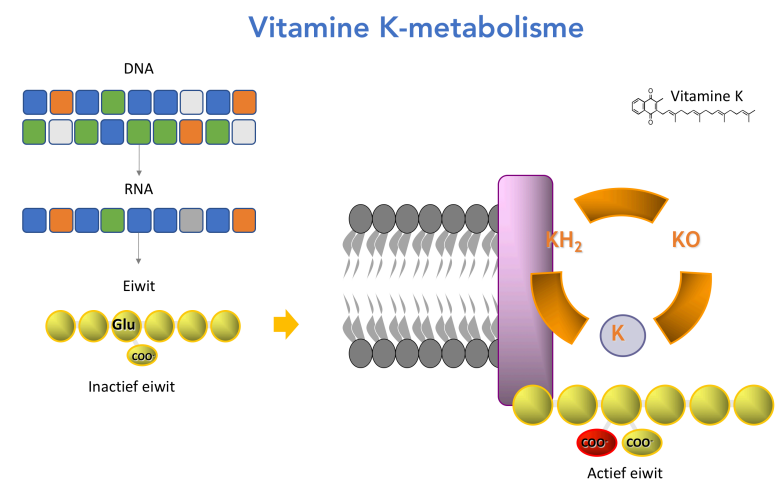

Figuur 17

Vitamine $\mathrm{K}$ is dus heel belangrijk voor de activiteit van vitamine K-afhankelijke eiwitten. Deze biochemische reactie is noodzakelijk voor het leven. DNA wordt via RNA vertaald in eiwit. In sommige gevallen zijn deze eiwitten dan nog niet functioneel. 
Ze moeten nog een verandering ondergaan, waardoor het eiwit op de juiste manier wordt gevouwen en pas dan biologische activiteit krijgt. Vitamine $K$ is als enig molecuul in staat deze specifieke reactie te starten. Vitamine $\mathrm{K}$ kan wel tot 1000 keer worden hergebruikt. Dit recycling mechanisme geeft aan hoe belangrijk vitamine $K$ is. De meeste van ons weten allang dat vitamine $\mathrm{K}$ heel belangrijk is - waarschijnlijk onbewust. Bij de geboorte van onze kinderen wordt als allereerste een injectie met vitamine $\mathrm{K}$ toegediend, omdat pasgeborenen een ernstig vitamine $\mathrm{K}$ te kort hebben. Doordat wij sinds de jaren 90 vitamine $\mathrm{K}$ toedienen, helpen we de stolling te activeren en verminderen de kans op ernstige hersenbloedingen.

In dezelfde periode dat vitamine $\mathrm{K}$ is ontdekt is ook warfarine ontdekt. Warfarine is een vitamine $\mathrm{K}$ antagonist, een stof die de werking van vitamine $\mathrm{K}$ tegen gaat. Deze vitamine $\mathrm{K}$ antagonisten zijn bij de meesten van $u$ beter bekend als bloedverdunners. Warfarine werd ontdekt toen koeien in de VS plotselinge dodelijke bloedingen vertoonden. Men kwam erachter dat dit kwam door dat het hooi besmet was met een schimmel. Deze schimmel bevatte een stof genaamd dicoumarol. Dicoumarol werd onder de naam Warfarine op de markt gebracht als rattengif. Als een Amerikaanse soldaat zelfmoord probeert te plegen door het slikken van dit rattengif, komt men erachter dat het gebruikt kan worden als antistolmiddel. Immers, warfarine heeft een "onset" van ongeveer 5 dagen voor het echt werkt. De Amerikaanse soldaat is dus twee dagen na inname van het rattengif naar het ziekenhuis gegaan en behandeld met vitamine $\mathrm{K}$, en dus overleefde hij dit zelfmoordavontuur. Toen men wist dat warfarine geschikt was als antistolmiddel werd het geregistreerd onder een andere naam: coumadine. Vitamine $K$ antagonisten, afgekort VKA, remmen de stolling door vitamine $\mathrm{K}$ recycling te blokkeren. Ze zorgen dus dat vitamine K-eiwitten inactief blijven. Het voor mensen op antistolling belangrijk te weten wat ze eten. Immers, vitamine $\mathrm{K}$ ingenomen met de voeding zal interfereren met de antistolling.

\section{3 oktober 2018 Wereld trombose dag}

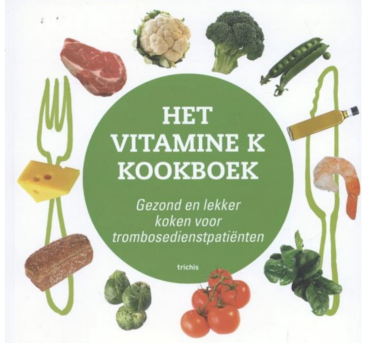

https://www.bol.com/nl/p/het-vitamine-k-kookboek/

https://www.trombosestichting.nl/bestellen/vitamine-k-kookboek/

\section{$\frac{\text { TRAPMBOSESTICHTING }}{\text { NEDERLAND }}$}

\section{Figuur 18}

Samen met collega Prof. Ten Cate heb ik een vitamine K kookboek samengesteld om mensen die VKA gebruiken te informeren over hoeveel vitamine $K$ ze eten. Het is namelijk voor een stabiele antistolling belangrijk om iedere dag eenzelfde hoeveelheid vitamine $K$ te eten. $I \mathrm{k}$ maak $\mathrm{u}$ hierop attent omdat het morgen 13 oktober wereld trombose dag is. 
Het heeft lang geduurd voor dat werd ontdekt dat de effecten van VKA niet beperkt bleven tot de stollingseiwitten in de lever. Dat dit zo lang heeft geduurd is een consequentie van "oog-kleppen" wetenschap, waar onderzoekers voor moet waken. Vaak zijn we te geobsedeerd in het mechanisme dat we onderzoeken, dat we andere aspecten uit het oog verliezen. Ons onderzoek heeft een belangrijke bijdrage geleverd aan de paradoxale effecten van VKA op de vaatwand.

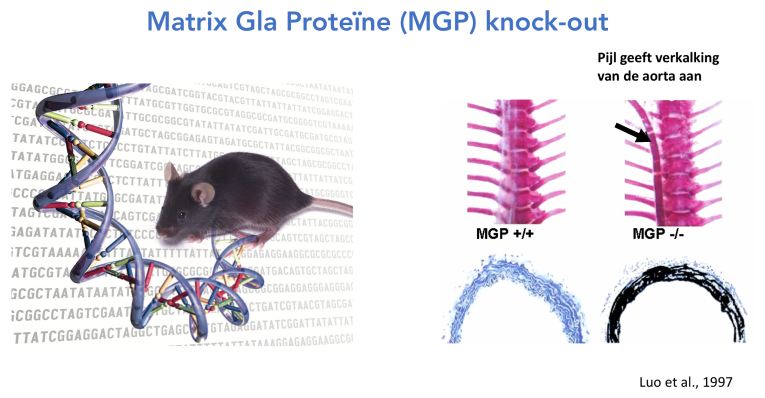

Figuur 19

Een van de vitamine K-afhankelijke eiwitten in de vaatwand is matrix Gla proteïne, afgekort MGP. De functie van dit eiwit wordt in 1997 gepubliceerd in het toonaangevende blad Nature. Op zoek naar de functie van MGP maakten de onderzoekers gebruik van een knock-out muis 12. Een knock-out muis is een muis waarbij men een stukje DNA verwijderd zodat de muis geboren wordt zonder het te onderzoeken eiwit. De muizen zonder het MGP werden normaal geboren, dat wil zeggen zonder zichtbare afwijkingen. Echter binnen een tijdsbestek van 2 maanden stierven alle muizen. De afwezigheid van MGP had als gevolg dat alle bloedvaten verkalkten waardoor deze door de stijfheid openbarsten en waardoor de muizen overleden aan bloedingen. Het mag dus duidelijk zijn dat met dit onderzoek een van de sterkste remmers van vasculaire verkalking was ontdekt: een vitamine K-afhankelijk eiwit.

\section{Medicatie geïnduceerde MGP "knock-out"}
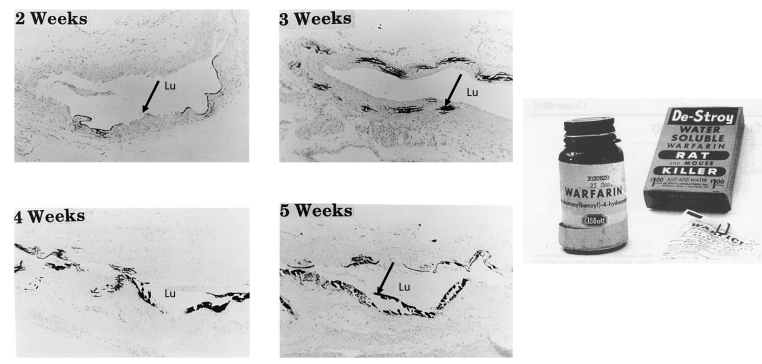

Figuur 20

Price et al 1998., Spronk et al., 2003., Schurgers et al., 2007 
Het belang van vitamine $\mathrm{K}$ voor de vaatwand werd aangetoond in ratten die VKA kregen toegediend. Ratten werden op een speciaal dieet met VKA gezet om een vitamine $K$ tekort in de vaatwand te induceren ${ }^{13}$. In de figuur boven mij ziet $u$ bij de pijlen in zwart de verkalking in de weefselplakjes van de bloedvaten. In een tijdsbestek van twee weken resulteerde de toediening van VKA in verkalking van de vaatwand, welke verder toenam naarmate het warfarine langer werd gegeven.

Uit deze resultaten werd echter niet duidelijk of VKA daadwerkelijk de functie van MGP beïnvloedde. Om deze vraag te beantwoorden heb ik tijdens mijn onderzoek naar de rol en functie van MGP, specifieke antilichamen gemaakt tegen de actieve en niet actieve vorm van MGP. De generatie van deze antilichamen was een belangrijke doorbraak, want met behulp van deze antilichamen wisten wij aan te tonen dat vooral de niet actieve vorm van MGP sterk geassocieerd is met verkalking.

\section{Inactief MGP en vasculaire verkalking}

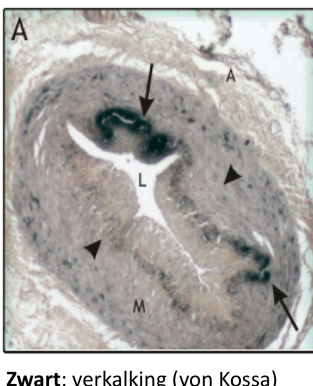

Zwart: verkalking (von Kossa)

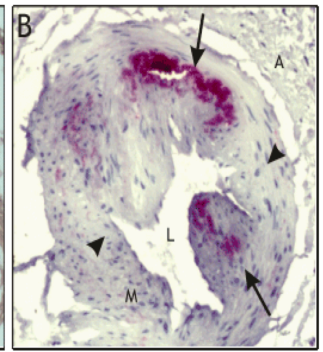

Rood: niet actief MGP (ucMGP)

Figuur 21

Ter illustratie een experiment waarin we een dun plakje humaan vaatweefsel hebben gekleurd voor kalk, aangegeven in zwart. Een opeenvolgend stukje weefsel is gekleurd voor de niet actieve vorm van MGP in rood ${ }^{14}$. $U$ ziet dat het niet actief MGP op dezelfde plaatsen te vinden is als waar de kalk in het bloedvat zich bevindt. Dit suggereert dat niet actief MGP veroorzaakt door een lokale vitamine $\mathrm{K}$ deficiëntie leidt tot verkalking.

Ik kon toen nog niet bevatten dat deze antilichamen mijn onderzoek een geweldige boost zouden geven. Ik word begin van deze eeuw door de Universiteit van Tübingen uitgenodigd om een lezing te geven over MGP. Het toeval wil, dat juist aan deze Universiteit Johannes Mönckeberg - ontdekker van de mediale verkalking - rector is geweest. Na mijn lezing besluiten we een gezamenlijk project te starten. Hierin wordt verkalking gemeten in aortakleppen van patiënten die wel VKA en patiënten die geen VKA krijgen ${ }^{15}$. Dit onderzoek leverde de eerste publicatie waarin het gebruik van VKA bij patiënten resulteerde in een toegenomen verkalking. Nu heeft onderzoek pas waarde als het ook bevestigd kan worden, liefst door anderen. 
Er zijn inmiddels vele studies uitgevoerd, en onze eerste paradoxale bevinding is nu, jaren later, eindelijk geaccepteerd. Dit was niet van zelfsprekend: Een geneesmiddel dat al meer dan 50 jaar wordt voorgeschreven en plots ter discussie staat. Voor de jonge onderzoekers onder ons het advies om niet enkel de gebaande paden te bewandelen maar durven "out-ofthe-box" te denken. Wetenschap is namelijk geen facebook, waar iedere dag duimpjes of schouderklopjes worden uitgedeeld, maar vergt volharding en doorzettingsvermogen.

Ik wil u twee voorbeelden presenteren om aan te geven dat VKA de verkalking van de vaatwand actief beïnvloed.

Ik schets u de casus: Een 50-jarige blanke man krijgt in 1988 een niertransplantatie. Het posttransplantatie verloop is prima. Begin 2007, bijna 20 jaar later, wordt hij opgenomen op de intensive care-afdeling met een sepsis-achtig ziektebeeld. Het ziekte verloop wordt gecompliceerd door nierfalen, waardoor er wordt gestart met dialyse-therapie. Daarnaast ontwikkelt hij atriumfibrilleren en wordt behandeling met een VKA gestart.

\section{VKA gebruik resulteert in vasculaire verkalking}

\section{Figuur 22}

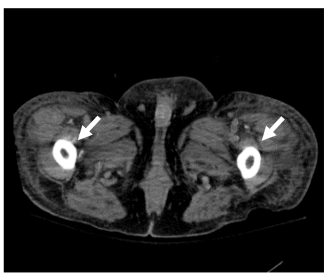

CT van de patient voor VKA

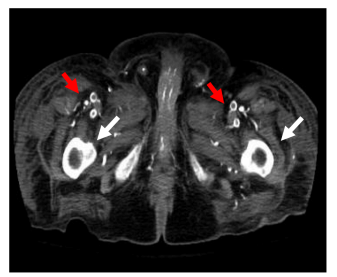

CT van de patient na 9 maanden VKA

Er wordt een CT-scan gemaakt van de patiënt ter hoogte van het bekken. De witte pijlen wijzen naar de bovenbenen van de patiënt. De situatie van de patiënt lijkt stabiel, maar hij overlijdt toch 9 maanden later. Op de rechter CT-scan zien u bij de rode pijlen dat er naast de bovenbenen nu nog enkele andere oplichtende structuren te zien zijn: dit is kalk in de bloedvaten. Deze verkalking ging gepaard met een sterk toegenomen inactief MGP. Ernstige verkalking van bloedvaten kan dus optreden in een tijdsbestek van 9 maanden ${ }^{16}$.

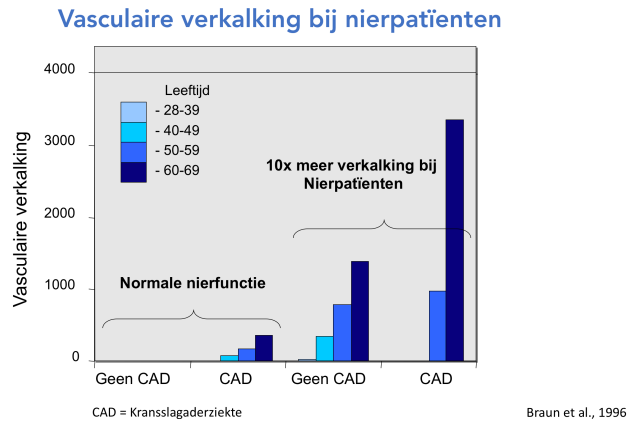

Figuur 23 
Een tweede voorbeeld zijn chronische nierpatiënten. Onze nieren zijn heel belangrijk en ze zorgen onder andere voor het verwijderen van afvalstoffen. Werken je nieren niet goed meer? Dan vergiftigt je lichaam langzaam. Mensen met chronische nierschade lopen een verhoogd risico op hart- en vaatziekten en dit is grotendeels te verklaren door de verkalking van de bloedvaten ${ }^{17}$. Een ernstige complicatie van chronische nierziekte is namelijk een verstoorde uitscheiding van zouten, zoals fosfaat en kalium. Het beleid van de nefroloog is om de voedingsinname voor fosfaat en kalium zo laag mogelijk te houden. Nu is het probleem dat kalium in groene groentes zit. En in groene groentes zit heel veel vitamine K1. Daarnaast is het advies om weinig fosfaat met de voeding in te nemen. Fosfaat zit onder andere in zuivel en kaas, en deze producten zijn rijk aan vitamine K2. Met andere woorden, het beleid van de nefroloog werkt een vitamine $\mathrm{K}$ deficiëntie in de hand, en daarmee dus verkalking. Maar het kan nog erger.
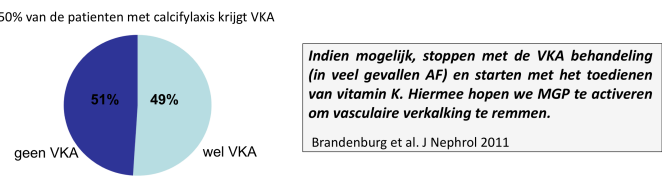

Figuur 24
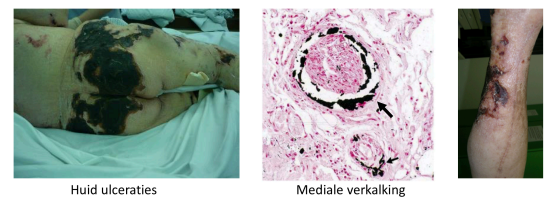

Ondanks de ernstige vitamine $\mathrm{K}$ deficiëntie in patiënten met nierfalen wordt nog te vaak gebruik gemaakt van VKA wat kan leiden tot calcifylaxis. Calcifylaxis is een zeldzame, levensbedreigende aandoening waaraan $80 \%$ van de patiënten sterft. Het wordt gekenmerkt door pijnlijke huidulceraties en verkalking van bloedvaten. Een van de grootste risicofactoren voor het ontwikkelen van calcifylaxis is het gebruik van VKA ${ }^{18}$.

Mede gebaseerd op ons werk heeft dit geleid tot nieuwe adviezen: vitamine K-antagonisten dienen gestopt te worden, en nieuw therapeutische strategieën zoals vitamine $K$ supplementen zouden overwogen moeten worden.

Ik wil hier zeker niet pleiten om VKAs in de ban te doen; ze zijn namelijk zeer belangrijk voor het verminderen van het trombose risico, een levensbedreigende conditie. Gelukkig zijn er nieuwe orale antistolmiddelen beschikbaar die hoogstwaarschijnlijk geen nadelige vaatwand effecten hebben. In samenwerking met farmaceutische industrieën onderzoekt mijn onderzoeksgroep momenteel de effecten van deze nieuwe orale antistolmiddelen op verkalking van de vaatwand. Hoewel verder onderzoek zeker nodig is, dienen artsen zich wel bewust te zijn dat VKAs, zeker bij langdurig gebruik, een extra risicofactor vormen voor verkalking. Ik zou dan ook willen pleiten voor nog meer samenwerking tussen de basaal onderzoekers en artsen: we moeten deze afstand beter overbruggen. Ik prijs mij dan ook gelukkig dat onze onderzoeksschool CARIM, vroege detectie en het slaan van bruggen tussen kliniek en prekliniek ondersteund. 


\section{Figuur 25}

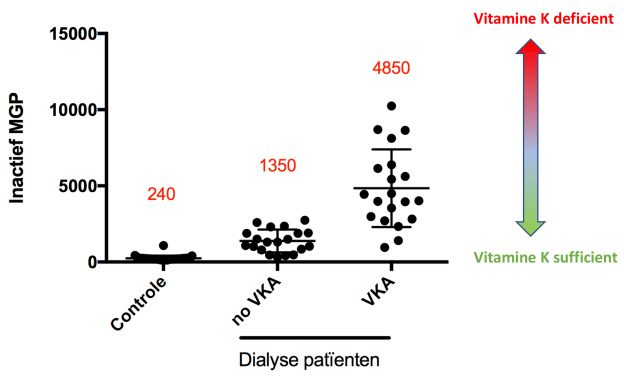

Wij stelden ons de vraag hoe we de vitamine $\mathrm{K}$ status van de vaatwand kunnen meten. Het is namelijk onmogelijk aan iedere patiënt een stukje vaatweefsel te vragen. Dit zou een aantal ethische dilemma's kunnen opwerpen. Wij hebben daarom een bloedtest ontwikkeld om zo de vitamine $\mathrm{K}$ status van onze vaatwand te bepalen. Hiervoor is gebruik gemaakt van onze MGP-antilichamen. In samenwerking met vele klinische afdelingen hebben wij inmiddels aangetoond dat een vitamine $\mathrm{K}$ deficiëntie in de vaatwand veelvuldig voorkomt, vooral bij dialyse patiënten. De antilichamen en octrooien rond MGP zijn inmiddels verkocht aan een de industrie. Door samen te werken met de industrie hopen we deze biomarker verder te ontwikkelen zodat deze uiteindelijk gebruikt kan worden in de kliniek.

VKA-gebruik zorgt voor een vitamine $\mathrm{K}$ deficiëntie en vergroot daarmee het risico op verkalking van bloedvaten. Op grond van deze bevindingen stelden wij de vraag: kan het toedienen van vitamine $K$ verkalking dan afremmen? Deze vraag lijkt eenvoudiger dan het is. Nieuwe medicatie of supplementen mogen niet zomaar in proefpersonen worden getest.

Experimenten in proefdieren zijn daarom belangrijk voor de medische wetenschap. Toch staat proefdieronderzoek onder grote maatschappelijke druk, veelal gebaseerd op emoties en niet op feiten. Dierexperimenteel onderzoek staat namelijk onder streng toezicht van verschillende commissies, nauwkeurig vastgelegd in de Wet op de Dierproeven. Alvorens met proefdieren te werken dient de onderzoeker een weloverwogen plan in te dienen dat wordt getoetst en beoordeeld. Pas na goedkeuring mag de onderzoeker met de grootst mogelijke zorgvuldigheid de dierproeven starten. Met de nieuwe wetgeving ligt er echter een enorm bureaucratisch gevaar op de loer. Ik zou willen pleiten voor minder bureaucratie en betere beeldvorming. Veel van de nieuwe geneesmiddelen die op de markt worden gebracht zijn mede door proefdierwerk tot stand gekomen. Ook de toegenomen kennis en nieuwe genetische technieken maken het mogelijk de menselijke conditie met steeds grotere precisie in dieren na te bootsen. Het is belangrijk de maatschappij op een zo transparant mogelijke manier in te lichten over het gebruik van proefdieren in onderzoek, en de winst die hier behaald wordt. Juist hier ligt een belangrijke taak voor onderzoekers en Universiteiten.

Terug naar de vraag: wat is het effect van vitamine $K$ op vasculaire verkalking. In dit experiment hebben wij proefdieren eerst VKA gegeven om verkalking van bloedvaten te induceren. Daarna hebben wij het dieet gewisseld en zijn we overgestapt naar vitamine K. 


\section{Vitamine K remt VKA geïnduceerde verkalking}

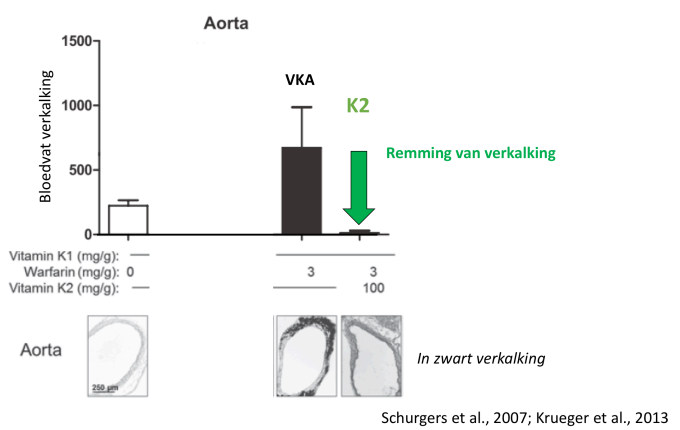

\section{Figuur 26}

In dit werk hebben wij als eersten laten zien dat vitamine $K$ in staat is de verkalking te remmen en zelfs ten dele op te lossen. Met name vitamine $\mathrm{K} 2$ had een groot effect op het verminderen van verkalking. In experimenteel vervolgonderzoek is gezocht naar een verklaring voor dit gunstige effect. Gebleken is dat na opname, voornamelijk vitamine K2 naar de vaatwand wordt getransporteerd.

Toch heeft het jaren geduurd voordat de gevestigde medische gemeenschap het aandurfde om vitamine $\mathrm{K}$ in te zetten als medicijn. Inmiddels hebben wij aangetoond dat het geven van vitamine $\mathrm{K}$ aan patiënten geen risico's kent. En de eerste publicatie met een positief effect van vitamine $K$ op het remmen van verkalking is inmiddels een feit ${ }^{19}$. Meerdere klinische studies zijn inmiddels gestart, in samenwerking met de afdelingen interne geneeskunde (Prof Bram Kroon) en cardiologie (Prof Crijns) van het MUMC+ en de afdeling nefrologie uit Aken (Prof Floege, Prof Kramann en Prof Brandenburg). Deze resultaten zullen nieuwe inzichten opleveren voor diagnostiek en therapie van hart en vaatziektes.

De toekomst ziet er rooskleurig uit. Mijn onderzoek heeft focus rondom de gladdespiercel als moleculair target voor verkalking. Het vinden van nieuwe voorspellende biomarkers voor verkalking is een van de speerpunten van ons onderzoek. Samen met collega Prof Reutelingsperger bouwen we aan onderzoek dat nieuwsgierigheid gedreven is en onze infrastructuur state-of-the-art. Het Biohybrid platform, dat wij samen hebben ontwikkeld met Prof Biessen is hier een eerste bewijs van.

Beeldvormende technieken zijn de laatste jaren sterk ontwikkeld om verkalkingen zichtbaar te maken. Het radio-isotoop Natrium Fluoride 18 maakt het mogelijk om met de beeldvormende PET-techniek, microcalcificaties te meten. Recentelijk is aangetoond dat $86 \%$ van de patiënten zonder zichtbare kalk op $\mathrm{CT}$, een positief PET-signaal heeft voor microverkalking. Deze ontwikkeling zal verder onderzoek naar de oorzaken van verkalking, het voorkomen of afremmen, alleen maar stimuleren. Een eerste gezamenlijke publicatie tussen onze afdeling Biochemie en de afdeling Nucleaire Geneeskunde op dit onderzoek is gisteren in de literatuur verschenen. 
It is not what you look at that matters, it is what you see.

- Henry David Thoreau

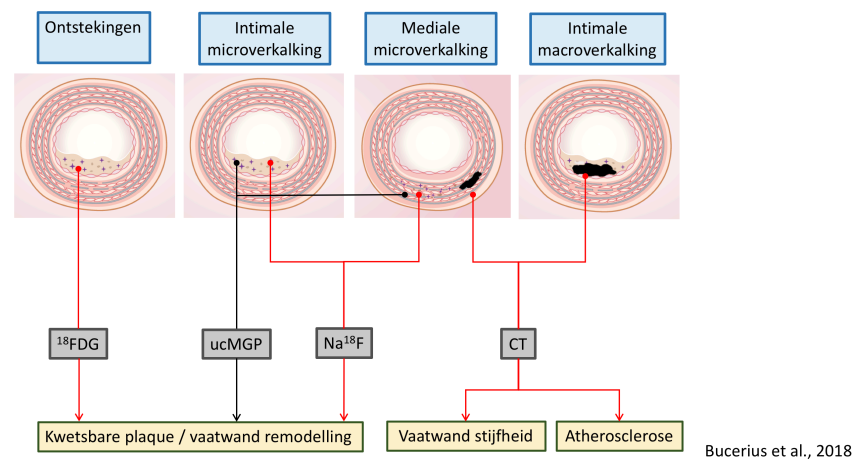

\section{Figuur 27}

We zullen dan ook de komende jaren inzetten op de ontwikkeling van nieuwe radiotracers voor de vroege detectie en behandeling van microverkalkingen. Ik hoop dat u mij toestaat hier nog jaren aan te mogen werken.

\section{De Universiteit}

Er is veel verandert over de jaren. De oude universiteit als instituut sterft langzaam omdat de ivoren torens worden verlaten, doordat professoren managers worden en studenten consumenten. Geld is de maat der dingen, de universiteit is ondernemend geworden. En hoe graag we het zouden willen, het is onmogelijk dit proces te keren: het is namelijk niet de universiteit die is veranderd, het is een totale maatschappelijke verandering ${ }^{20}$.

In een tijd van "wisdom of the crowd" is er grote behoefte aan een volledig betrouwbaar instituut - dat betekent transparantie, en de wil om absolute rekenschap af te leggen. Mensen vertrouwen of negeren de wetenschap, en Dr. Google lijkt het te winnen van welopgeleide artsen en wetenschappers. Steeds meer hoogopgeleide mensen laten hun kinderen niet meer vaccineren, veelal ingefluisterd door onjuistheden. Mensen zijn argwanend ten opzichte van de doordachte en kritische wetenschap. In een wereld waar "fake-news" en "alternative facts" overheersen, heeft juist de wetenschap de belangrijke taak om feiten te genereren.

Eenieder moet zich realiseren dat de meeste besluiten die we vandaag de dag nemen gebaseerd zijn op feiten, feiten afkomstig van wetenschappelijk werk. Daarom moeten we blijven verkondigen: de wetenschap is van iedereen, en voor iedereen en hieraan ontleent de universiteit van de toekomst haar bestaansrecht. De sleutel ligt in goede communicatie. 


\section{Ik ben aangekomen bij het laatste deel van mijn openbare les, het dankwoord}

Mijn leven lijkt op dat van een spannend jongensboek. Ik voel me dan ook ontzettend bevoorrecht. Ik wil graag een aantal mensen bedanken die een meer dan belangrijke rol hebben gespeeld in dit boek, zowel academisch als daarbuiten.

Ik dank het college van bestuur van de Universiteit Maastricht, het bestuur van CARIM en de decaan van de faculteit van Health, Medicine en Life Sciences voor het in mij gestelde vertrouwen. Ik wil het toptalenten programma bedanken. Een groep geselecteerde wetenschappers uit verschillende disciplines voor een leiderschapscursus. Ik wist in het begin niet waarvoor ik precies geselecteerd was, maar dat zegt waarschijnlijk meer over mij. Ik prijs mij echter zeer gelukkig deel te zijn van mijn groepje.

Dr. Vermeer, beste Kees. Ik kwam in 1995 voor een stage bij jou, ik toen nog met lange haren en een oorbel. Toch zag jij iets in mij: ik ben bij jou afgestudeerd en gepromoveerd, Jij was mijn begeleider van het eerste uur. Ik heb ontzettend veel van je geleerd, met name hoe je wetenschap en industrie kunt combineren in onderzoek. Samen hebben we het vitamine K en MGP-onderzoek opgezet, en hier vloeide in 2001 het spin-off bedrijf VitaK uit voort. Jij bent inmiddels welverdiend met pensioen en ik hoop dat ik ons werk nog lang kan voortzetten.

Prof. Reutelingsperger, beste Chris. Toen ik in 2009 een vaste positie bij de vakgroep Biochemie kreeg was het een "no-brainer met wie ik zou samenwerken. Celdood gecombineerd met mummificeren - stijver en dodelijker kan het niet. Niets is minder waar ons onderzoek floreert en er staat ons nog veel moois te wachten. Jou kennis, inzicht en kunde zijn ongekend op velerlei vlakken. Ik ben je dankbaar voor het blindelingse vertrouwen en de ruimte die je mij geeft om mijn eigen lijn uit te bouwen.

Prof Hackeng, beste Tilman. Dank, dat jij me hebt voorgedragen voor het toptalentenprogramma. Maar vooral wil ik je bedanken voor je nimmer aflatende enthousiasme en de kansen die jij mij geeft. Jij hebt mij geleerd dat vriendschap en vertrouwen de basis vormt voor succes, ook in de wetenschap. Sinds een jaar besturen we samen de afdeling Biochemie en daar ben ik heel trots op. Want laten we eerlijk zijn - het is toch echt de mooiste en beste vakgroep.

Ik wil mijn collega's bij de afdeling biochemie bedanken voor hun collegialiteit en gezelligheid. Hier voel ik me al meer dan 20 jaar thuis. Ik beschouw het als een voorrecht hier deel van uit te maken.

Cecile, Petra, Lisette, Niko, Peter en Gosia - jullie vormen de vaste kern, het stevige skelet van onze groep. Jullie weten als geen ander wat nodig is om een multidisciplinaire en multiculturele groep te managen. Ik hoop dat ik nog vele jaren met jullie mag samenwerken!

De klinische AIOs Ellen, Roger, Mathias, en Frederique voor het vormen van de brug tussen biochemie en de kliniek. 
Martijn, Dennis en Brecht, alfamannetjes van het eerste uur. Jullie hebben een gladdespiercel fundament van beton gecreëerd waar onze groep nu op verder bouwt.

My European group: based on grants from The Netherlands, Germany, Norway and Europe, PhD students and Early Stage Researchers: Rick, Armand, Ploi, Angelina, Grzeg, Cengiz, and Niko. Our multicultural group clearly represents one Europe and demonstrates that together we are stronger. It is a privilege to work with such great talent from all over the world. Your enthusiasm and team-spirit will make our future bright.

A special thanks to Prof Jahnen-Dechent, dear Willi, Mister Fetuin! Our calci-club meetings are the basis for the INTRICARE success. This offers us even more discussions, also about NSU motorcycles...Vielen dank Willi!

I want to thank Prof Floege, Prof Brandenburg and Prof Kramann for our longstanding collaboration. I am very pleased to be now formally part of your research group in Aachen.

Dear Prof. Shanahan, dear Cathy. You came to Maastricht some 20 years ago to collaborate on MGP. The fact that we are still collaborating, even more than ever, is based on our passion for calcification, and on our friendship. I am very honored that you are present here today.

Een groot deel van mijn research steunt op translationeel onderzoek. Ik voel mij bevoorrecht samen te mogen werken met vele afdelingen in het MUMC. Ik hoop dat dit de komende jaren alleen maar meer zal worden.

Dank aan Marianne Quaden voor alle steun en hulp rondom deze dag.

Ik ben opgegroeid in Doenrade, een klein dorpje vlak aan de grens. Samen met mijn zus en mijn ouders heb ik hier een zorgeloze jeugd gehad. Als ik nu terugblik op deze tijd realiseer ik mij hoe mooi deze tijd was, en dat dit de basis heeft gevormd voor mijn verdere leven.

Mijn ouders, ik ben er ongelooflijk trots op dat jullie mijn ouders zijn. Ik heb het jullie zeker niet altijd gemakkelijk gemaakt, en ik kan me voorstellen dat jullie vaker dan eens hebben gedacht wat jullie met mij aan moesten. Toch zijn jullie altijd in mij blijven geloven en hebben jullie mij gesteund in alle keuzes die ik heb gemaakt. Jullie staan altijd voor mij, en ons gezin klaar, en hebben het fundament gelegd om mij te ontwikkelen tot wie ik nu ben.

Mijn schoonouders, Zef en Tiny. Helaas zijn jullie niet meer onder ons maar jullie invloed is onmiskenbaar. Wat zouden jullie vandaag genoten hebben.

En als laatste mijn eigen gezin: wat zou ik zonder jullie moeten?

Juul en Sam, woorden schieten te kort om aan te geven hoe trots ik op jullie ben. Jullie weten met hoeveel plezier ik iedere dag naar mijn werk ga, maar houden doe ik van jullie. Jullie maken mijn leven mooi en compleet, en het wordt alleen maar leuker. 
Lieve Romy, mijn rots in de branding en onmisbaar. Mijn dank en liefde aan jou is niet in woorden te vangen. 25 jaar geleden vroeg ik of je met mij wilde trouwen, ik kon een baan op de Universiteit krijgen, maar moest dan wel onder diensttijd uit. Jij twijfelde geen moment en stond en staat nog steeds achter mij. Zonder jouw onvoorwaardelijke liefde en steun had ik hier vandaag niet gestaan. Maar een ding staat vast: samen zijn wij sterker!

Ik heb gezegd! 


\section{Referenties}

1. Murphy W, Nedden Dz D, Gostner P, Knapp R, Recheis W, Seidler H. The iceman: discovery and imaging. Radiology. 2003;226:614-629.

2. Allam AH, Thompson RC, Wann LS, Miyamoto MI, Nur El-Din AE-H, El-Maksoud GA, Al-Tohamy Soliman M, Badr I, El-Rahman Amer HA, Sutherland ML, Sutherland JD, Thomas GS. Atherosclerosis in ancient Egyptian mummies: the Horus study. JACC Cardiovasc Imaging. 2011;4:315-327.

3. Hodgson J. Treatise on the Diseases of Arteries and Veins. 1815;

4. Virchow R. Cellular Pathology. Nutr Rev. 1858;

5. Mönckeberg J. Uber die reine mediaverkalkung der extremitätenarterien und ihr verhalten zur arteriosklerose. Virchows Arch Pathol Anat. 1902;171:141-167.

6. Blumenthal HT, Lansing Al, Wheeler PA. Calcification of the Media of the Human Aorta and Its Relation to Intimal Arteriosclerosis, Ageing and Disease. Am J Pathol. 1944;20:665-687.

7. Rennenberg RJMW, Kessels AGH, Schurgers LI, van Engelshoven JMA, de Leeuw PW, Kroon AA. Vascular calcifications as a marker of increased cardiovascular risk: a meta-analysis. Vasc Health Risk Manag. 2009;5:185-197.

8. Roijers RB, Debernardi N, Cleutjens JPM, Schurgers LJ, Mutsaers PHA, der Vusse van GJ. Microcalcifications in early intimal lesions of atherosclerotic human coronary arteries. Am J Pathol. 2011;178:2879-2887.

9. Kramer CK, Zinman B, Gross JL, Canani LH, Rodrigues TC, Azevedo MJ, Retnakaran R. Coronary artery calcium score prediction of all cause mortality and cardiovascular events in people with type 2 diabetes: systematic review and meta-analysis. BMJ. 2013;346:f1654.

10. Williams GC. PLEIOTROPY, NATURAL SELECTION, AND THE EVOLUTION OF SENESCENCE. Evolution. 1957;11:398-411.

11. Dam H. The discovery of vitamin K, its biological functions and therapeutical application. Nobel price lecture. 1946;

12. Luo G, Ducy P, McKee M, Pinero G, Loyer E, Behringer R, Karsenty G. Spontaneous calcification of arteries and cartilage in mice lacking matrix GLA protein. Nature. 1997;385:78-81.

13. Price $\mathrm{P}$, Faus $\mathrm{S}$, Williamson $\mathrm{M}$. Warfarin causes rapid calcification of the elastic lamellae in rat arteries and heart valves. Arterioscler Thromb Vasc Biol. 1998;18:1400-1407.

14. Schurgers L, Teunissen KJF, Knapen MHJ, Kwaijtaal M, van Diest R, Appels A, Reutelingsperger CP, Cleutjens JPM, Vermeer C. Novel conformation-specific antibodies against matrix gammacarboxyglutamic acid (Gla) protein: undercarboxylated matrix Gla protein as marker for vascular calcification. Arterioscler Thromb Vasc Biol. 2005;25:1629-1633.

15. Schurgers $\sqcup$, Aebert H, Vermeer C, Bültmann B, Janzen J. Oral anticoagulant treatment: friend or foe in cardiovascular disease? Blood. 2004;104:3231-3232.

16. Hristova M, van Beek C, Schurgers L, Lanske B, Danziger J. Rapidly progressive severe vascular calcification sparing the kidney allograft following warfarin initiation. Am J Kidney Dis. 2010;56:11581162.

17. Braun J, Oldendorf M, Moshage W, Heidler R, Zeitler E, Luft FC. Electron beam computed tomography in the evaluation of cardiac calcification in chronic dialysis patients. Am J Kidney Dis. 1996;27:394-401.

18. Brandenburg VM, Cozzolino M, Ketteler M. Calciphylaxis: a still unmet challenge. J Nephrol. 2011;24:142-148.

19. Brandenburg VM, Reinartz S, Kaesler N, Krüger T, Dirrichs T, Kramann R, Peeters F, Floege J, Keszei A, Marx N, Schurgers L, Koos R. Slower Progress of Aortic Valve Calcification With Vitamin K Supplementation: Results From a Prospective Interventional Proof-of-Concept Study. Circulation. 2017;135:2081-2083.

20. Zwaan van der, B. Haalt de Univeriteit 2040?. Een Europees perspectief op wereldwijde kansen en bedreigingen. ISBN 978946298415 8. 2017. 